\title{
The Knowledge Age Requires a New System of Education
}

\author{
Zoran Lovreković \\ The Higher Education Technical School of Professional Studies, \\ Novi Sad, Serbia
}

lovrekovic@vtsns.edu.rs

\begin{abstract}
There is Paradigm shift in the Knowledge age - from the competitive advantage based on collecting and owning information to the one based on the ability to create new working knowledge. This requires an entirely new view on what the Education is and what it must be. The number of innovations, business process reengineering initiatives and incremental improvements of processes or products is negligible in comparison with the possibilities. Graduate students are poorly qualified to create new working knowledge in their future work environments, which is the basic postulate to reach the global business competitiveness. The paper discusses application of four types of knowledge conversion described by Nonaka and Takeuchi, as well as the need that students attain declarative, procedural, causal, conditional and relational knowledge in a proper ratio during their education. The influence of these knowledge management concepts to the increase in students' ability to create new working knowledge is also discussed.
\end{abstract}

Keywords: knowledge, education, tacit knowledge, educational system, knowledge creation...

\section{Introduction}

Too much focused on "scientific" research, many business schools hire professors with limited experience from the real business world and therefore produce students that are not prepared to handle complex non-quantifiable problems i.e. real managers' problems. For many years, MBA programs were respected with growing popularity in academic world and business world alike. Today, however, MBA programs are facing a lot of criticism because of failure to equip the students with certain skills necessary for future leaders. Moreover, MBA programs today do not progress students towards leading positions in companies. These condemnations come from students, employers, media, but also from some deans of the most prestigious Americans business schools, including Dipak Jain from Kellogg School of management from North Western University, one of the best ranked in USA (O'Toole, 2005.).

Similar conclusions may be extended to other streams of master and undergraduate programs,

Material published as part of this publication, either on-line or in print, is copyrighted by the Informing Science Institute. Permission to make digital or paper copy of part or all of these works for personal or classroom use is granted without fee provided that the copies are not made or distributed for profit or commercial advantage AND that copies 1) bear this notice in full and 2) give the full citation on the first page. It is permissible to abstract these works so long as credit is given. To copy in all other cases or to republish or to post on a server or to redistribute to lists requires specific permission and payment of a fee. Contact 0HPublisher@InformingScience.org to request redistribution permission. because in developed economies there is paradigm change: from the era of having comparative advantage based on possessing information to the era of getting comparative advantage based on ability to create new knowledge that results in the following (Lovreković, 2004.):

- new technologies,

- new products, 
- $\quad$ capability to make products according to fully specified needs, demands and specifications of a known consumer,

- new processes,

- new quality,

which all together produces excellent customer satisfaction.

In the situation when knowledge is outdated after only a few years, companies must generate new knowledge through innovation, creativity and highly efficient working capability in order to stay competitive.

The most valuable characteristics of the knowledge workers (workers of the future) are the ability to feel good in conditions of the indecision and in ability to perceive the continually changing business not as threats but as possibilities. It is impossible to get that kind of workers without a new view of what kind of education we need (Safo, 2000).

\section{Why Classic Education Doesn't Prepare Students for Creating New Working Knowledge}

How to prepare the students to be able and willing to produce new knowledge within their job, in order to make their future companies more competitive? What kind of education has to be given to students in order to increase creativity, intuition, desire for research and capability to make new knowledge?

Knowledge can be (Zack, 1999):

- declarative (knowing something about something or someone)

- $\quad$ procedural (knowing how)

- $\quad$ causal (knowing why)

- $\quad$ conditional (knowing when), and

- $\quad$ relational (knowing who/what, with whom/what)

Classical educational system teaches the students mainly declarative knowledge. This is the knowledge that can be externalized, i.e., explicit knowledge noted in books and notebooks. Testing this kind of knowledge is easiest through classical forms of students' assessment such as colloquia, tests, written exams and oral examinations. The mark that a student gets is the result of testing this kind of knowledge. Furthermore, this is also the kind of knowledge easiest to transfer and adopt, so that it can be possessed and acquired by those professors that has no practical experience in given subject. These professors look like swimming instructors that know all about swimming and will teach you everything about swimming (hydrodynamics, swimming styles, comparing the styles, history of swimming, Olympics results in swimming,...), but they themselves cannot swim and have never swam. At the same time, by manipulating the acquired declarative knowledge (categorizing it, linking it and putting it in the new context), they create new (again declarative) knowledge and publish new, highly valued scientific papers, and increase their personal professional and scientific rating.

Procedural and causal knowledge (related to skills and attitudes) is hardest to get. By its nature, this knowledge is tacit and hard to code, and can't be learned by just reading the books, but can be obtained through practical experience and from solving real problems. These are normally adopted during the probation period of work. The problem here is that this kind of knowledge is 
usually outdated, so that "good old experts" are teaching students to work the way it was done some 30 or 40 years ago, when they were trainees (Lovrekovic, \& Djurica, 2003.)

Without being equipped to create new procedural and causal knowledge, new specialists are not very useful. Overloaded with declarative knowledge and with no capability to create new procedural knowledge, the future specialists become precarious, scared and incapable to become flywheel of changes. Just the opposite, they become very resistive to necessary changes in business. (Lovrekovic, \& Djurica, 2003.).

\section{How Do Knowledge Management Concepts Help to Increase the Students' Capabilities to Make New Working Knowledge?}

There are four types of conversion (making new knowledge) (Nonaka, \& Takeuchi, 1995; Ruhe, 2001):

- Socialization: process of creating tacit knowledge, through business training such as apprentice work.

- Internalization: the process of converting explicit knowledge into tacit, through using documentation and literature during solving practical problems.

- Externalization: process of conveying the tacit knowledge into explicit concepts such as written documents.

- Combination: sorting, adding, combining and categorizing the knowledge can lead to new knowledge.

All four processes must be included so that one can have capability of making new knowledge.

Through socialization, student/apprentice develops tacit knowledge of his own by solving practical problems, relying on tacit knowledge of the tutor. On the other hand, tutor is guiding the apprentice using his tacit knowledge applied on practical problem. Through this interaction while solving practical problems, the student learns procedural and causal knowledge and qualifies to make his own knowledge.

Internalization process is also focused on acquiring and developing skills of creating the own tacit knowledge (primarily procedural and causal), but it is different from socialization as the mentor/tutor is replaced by mentor's externalized knowledge. The mentor tries to express his tacit knowledge into explicit knowledge, which the student converts into his own tact knowledge while using it to solve real problems. Since it is not possible to code tacit knowledge in full, it is obvious that internalization is less suitable then socialization. This is the reason why socialization must be the primary choice for creating tacit knowledge. Internalization can only be the complement to socialization, once the apprentice is so advanced that he/she is capable of self-mentoring.

Externalization allows the usage of internalization by writing tacit knowledge into explicit forms that can later be used later for internalization. With this approach, bigger number of students can be included in obtaining tacit knowledge then in internalization.

Combination is very often identified with scientific research and science. Combination is usually the dominant part of formal educational methods. However, it doesn't lead to making and developing tacit knowledge, as it mostly favors the declarative knowledge. This is the root of the weaknesses of the school today.

Knowledge is information that changes something or someone, making the person or organization capable of different or more efficient acting (Drucker, 1989). In order to have 
knowledge, it is important to have all of four types of knowledge conversion and all of five categories of knowledge through educating system.

Socialization must be the primary way of knowledge conversion, particularly in the beginning of every course/subject during the formal education. Professors must be master tutors and students must be apprentices. For this reason, professors must have not only declarative, but also procedural, causal, conditional and relational knowledge relevant for their subject and also in the wider area for which the school educates the students. Hence professors must be well equipped with practical experience, skills and attitudes. They should not just talk to the students, but also guide and lead them through solving real problems. Only then, through interaction with professor and within themselves, students can develop their own tacit knowledge. When you hear something, you often forget it quickly. When you see something, you remember it much better and longer. But only when you do something, you will fully understand it (Gerber, 2001). In this way, declarative knowledge adopted by students is only the vehicle to achieve the primary target: creating their own procedural, causal, conditional and relational knowledge through experience, skill development, creativity and initiative.

In cases when there are too many students, i.e. not enough time to devote to every student, internalization may be a substitution for socialization. Internalization is fully applicable in latter phases of a particular course, since students then have acquired a required level of skills for doing internalization.

Externalization is necessary for better overview, understanding and expression of the our own tacit knowledge.

Combination can be practiced in parallel with all other conversion types during complete process of education, but it mustn't be its own purpose, nether to congest declarative knowledge.

The practical meaning of this is the following (Lovrekovic, Abramovic, \& Nikolic, 2006):

- $\quad$ Professor should not be fixed only on theory of how thing should be done, but also must solve real practical problems together with students, like the tutor works with apprentices.

- $\quad$ Students must learn to use books and other documentation to solve practical problems, not just to memorize the facts.

- Student projects have to be taken from real world, appropriate to the problems he/she will have to solve at the workplace.

- Work in real world is usually team and multidiscipline work, and has to be the same way in educational process. Professors from different subjects must cooperate and organize student teams together, similar to reengineering business process in industry. (Lovreković Z. , 2003. and Lovreković Z. , 2000.)

- $\quad$ Validation of the success in educational process (giving students marks for their work) must be changed. The goal of education is that students become masters in solving the problems they will be solving at the workplace. Hence assessment (giving marks) should be oriented in the same way. Through mentoring work, professor should assess the student's ability to identify the problem, capabilities to solve it, initiative and passion in solving it, and the ability to create new knowledge. Also, team working ability and comprehending the problem in a wider context should be marked. Hence a part of the assessment is the student's work on solving the problem and the other part is the problem solution (Lovrekovic, 2003; Lovreković, Ristić, \& Runić, 2007) 
- $\quad$ Professors must work on developing suitable methods for externalization of tacit knowledge by preparing tutorials, additional software for this purpose and so on. This kind of development has to be done as a team work, both from professor side and from student side.

- $\quad$ Professors should be obliged to develop contacts and cooperation with companies as a part of his professional duties.

- In order to educate and evaluate students, professor must evaluate every student on the project in the following:

- What are the facts that student knows about the subject,

○ Does student know how to solve different problems from the subject (procedural knowledge, skills),

- Does the student really understand the problem, the goals and the tasks that need to be done in order to achieve those goals,

○ Does the student know the procedures in solving the problem,

- Is the student a real team player, and how does student look for solution of given problem and capability of the student to handle non standard problems.

\section{Conclusion}

Through the formal educational system students usually adopt declarative knowledge, while other types of knowledge, particularly procedural and causal knowledge, are not sufficiently present. This is the main reason for low ability of organizations to create new working knowledge.

There is no appropriate proportion among the four types of knowledge conversion, and it is the main reason for lack of procedural and casual knowledge among the students.

Better usage of knowledge management concepts, with approach of Nonaka and Takeuchi (1995) about necessity of presence of all four types of knowledge conversion, as well as all five types of knowledge, will prepare students for real tasks in real companies they will enter upon graduation.

By using the concepts mentioned above, students' capability to create new knowledge on their future job would improve, which will increase the amount of innovation, company profitability the overall competitiveness of organizations.

\section{References}

Drucker, P. (1989). The new realities. New York: Harper\&Row.

Gerber, M. (2001). The e-myth revisited: Why most small business don't work and what to do about it. New York: Harper Business.

Lovreković, Z. (2000). Reengineering processes in education- Case study of the VTS Novi Sad. Proceedings of the 1st Conference "Reengineering of the Business Processes", Zobnatica, Serbia.

Lovreković, Z. (2003). Education for post-industrial age. Proceedings of the 1st Conference "On the road to the Knowledge Age", Faculty of Management Novi Sad, Zobnatica, Serbia.

Lovreković, Z. (2004). What's the purpose of the knowledge management? Proceedings of the 2nd Conference "On the road to the knowledge age", Valdanos, Montenegro.

Lovrekovic, Z., Abramovic, B., \& Nikolic, D. (2005-2006). Research on the impact of knowledge management concept on capacity building among students for creating new working knowledge in future companies. Interregional International Cooperation Project, The Republic of Serbia, The Autonomus 
Province of Vojvodina, The Executive Council of the AP Vojvodina-Provincial Secretariat for science and technological development.

Lovreković, Z., \& Djurica, M. (2003). Information systems for production management: Does the educational system meet the changing requirements of the Yugoslav industry? Proceedings of the Portland International Conference on Management of Engineering and Technology-PICMET03, Portland, Oregon, USA.

Lovreković, Z., Ristić, I., \& Runić, M. (2007). Web tools for support of tutorial work with students. Proceedings of ETAI2007-VIII Macedonian National Conference with International Participation, Ohrid, FYROM.

Nonaka, I., \& Takeuchi, H. (1995). The knowledge-creating company. New York: Oxford University Press.

O'Toole, J. (2005, May). How business schools lost their way. Harvard Business Review.

Ruhe, G. (2001). Learning software organisation. Handbook of software engineering and knowledge engineering. World Scientific.

Safo, P. (2000). Knowledge and intuition in internet economy. Ekonomska Politika, No. 2508, Beograd, 2930.

Zack, M. (1999). Developing a knowledge strategy. California Management Review, 41(3), 125-145.

\section{Biography}

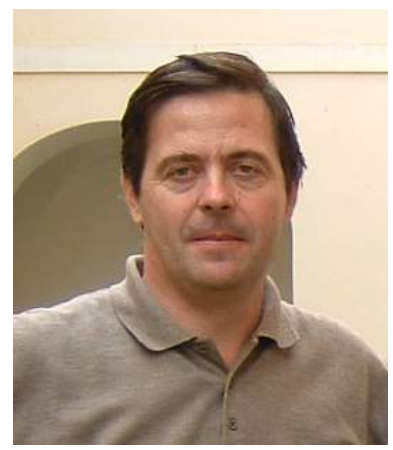

Zoran Lovrekovic is a professor at the Higher Education Technical School of Professional Education, Novi Sad, Serbia. He teaches courses in Applied Databases, Management Information Systems and E-Business. He received Ph.D. degree in IT (IT in production management). His research interests include knowledge management systems and expert knowledge in object and internet programming. 